\title{
ASÍ QUE PASEN CINCO AÑOS Y SU PUESTA EN ESCENA MULTIMEDIA. APUNTES SOBRE EL ESPECTÁCULO DE CATERINA GENTA Y MARCO SCHIAVONI
}

\author{
Milena LOCATELLI
}

\author{
Doctora por la Universidad de Pisa (Italia) \\ milena.locatelli@gmail.com
}

Resumen: El estudio analiza la puesta en escena multimedia de Así que pasen cinco años por parte de Caterina Genta y Marco Schiavoni. A través de un recorrido que compara los espacios dramáticos y los lugares escénicos, y una observación explicativa de la interpretación de las indicaciones lorquianas, se sugiere la importancia fundamental de la pieza en la producción teatral del autor andaluz y su posición de obra vanguardista representable.

Abstract: This paper examines the multimedia performance of Asi que pasen cinco años by Caterina Genta and Marco Schiavoni. By means of a comparison between the dramatic content of the text and the actual staging of the show as well as a reflection on the interpretation that the two artists gave of Lorca's specific indications, the fundamental importance of this text in the context of the Andalusian author's theatrical productions is analyzed, while considering its position and relevance as an work of the avant-garde representable. 
Palabras clave: Federico García Lorca. Así que pasen cinco años. Escena multimedia. Surrealismo. Tragedia.

Key Words: Federico García Lorca. Así que pasen cinco años. Multimedia Performance. Surrealism. Tragedy.

Es cierto que a lo largo del tiempo Así que pasen cinco años no ha tenido la misma suerte escénica que La casa de Bernarda Alba o Bodas de sangre. Esto es, sin duda, una de las obras menos conocidas del dramaturgo español y su puesta en escena, para los pocos que se atreven a representarla, es una labor no exenta de riesgos.

Concebida durante el periodo neoyorquino y, junto con El Público, perteneciente al teatro imposible, Así que pasen cinco años es el banco de pruebas mediante el cual el autor se esfuerza por elaborar, a su nuevo modo vanguardista, una obra para ser representada. El Público, sin embargo, permanecerá para él irrepresentable: «No se ha estrenado ni ha de estrenarse nunca, porque... "no se puede» estrenar"», declara Lorca en 1933.

A pesar de esta admisión de representabilidad, Así que pasen cinco años no es un texto fácil. Los aspectos enigmáticos de la obra, que intrigan a los directores e intérpretes más audaces, fácilmente se prestan a erigirse en una trampa que lleva indefectiblemente a un hermetismo sin salida.

En realidad, Lorca crea un texto de varias posibilidades que se presta deliberadamente a diferentes interpretaciones. A este propósito, Ucelay (2003: 137 ) indica que «la obra no es críptica. La actidud del poeta es en casos ambigua y abierta por tanto a la interpretación». Ambigua porque es abierta, según creo.

Lo que este texto tiene de extraordinario es de hecho su generosidad dramatúrgica. Desde un punto de vista formal, va de la poesía a la prosa con una exactitud y una pertinencia que recuerda al Lorca más maduro; desde el contenido, introduce y desarrolla de manera muy original para su época temáticas que evolucionarán en las tragedias posteriores ${ }^{1}$.

Así que pasen cinco años es una obra que representa, sobre todo, una reflexión del autor sobre el género dramático y su función social y artística. Por

\footnotetext{
2009).

${ }^{1}$ En un trabajo reciente apunto la relación entre Así que pasen cinco años y la tragedia (Locatelli,
} 
esta razón es un instrumento esencial si se quiere comprender un poco más la cosmovisión teatral lorquiana.

\section{LA PUESTA EN ESCENA MULTIMEDIA DE GENTA Y SCHIAVONI}

El espectáculo de Caterina Genta y Marco Schiavoni disipa lo críptico que pudiera existir en la obra. Puesto en escena, por primera vez, en el Teatro dell'Orologio de Roma, en mayo de 2006, se ha seguido representando hasta el pasado mes de febrero de 2009 en el Teatro Greco y será representado «durante al menos cinco años», prometen sus creadores.

La única actriz de carne y hueso presente en el escenario es la bailarina/cantante Caterina Genta, quien interpreta, tanto en el tablado como en vídeo, el papel del Joven, de la Mecanógrafa y del Maniquí.

El espectáculo se sirve de actores digitales proyectados sobre tres pantallas de plasma de formas y tamaños diferentes y basa sus diálogos en un mecanismo de relojería, puesto que la actriz dialoga con personajes virtuales previamente filmados. Es justamente una compañía digital la que habita el escenario y de esta manera está presentada en el programa de mano del espectáculo.

La puesta en escena multimedia de Así que pasen cinco años multiplica visual y acústicamente las dimensiones señaladas por el texto, expresando su núcleo esencial y dándole amplio vuelo. La aparente ambigüedad genera profundización, azar exacto, que habla con las palabras de Lorca y es un homenaje puro al poeta.

Lo que en el texto es alusión densa, aquí se convierte en generosa interpretación. El espectáculo muestra una profunda comprensión por el Lorca imposible. En él, la citada generosidad del texto se completa con la danza, la música y las videoproyecciones.

Hay que recordar que en la concepción de teatro total de Lorca convergen «drama, poesía, música, baile, ritmo, color, escenografía» (Ucelay, 2003: 133), así que la elección de una puesta en escena donde se utilizan actuación, baile, música y vídeo es muy adecuada.

En la pantalla más grande, que constituye el fondo del escenario, se proyectan los espacios de los tres actos. A estos se añaden ampliaciones escenográficas de los lugares indicados en las acotaciones, que insisten en la 
connotación simbólica de los espacios del texto y que se proyectan en las pantallas más pequeñas a la derecha y a la izquierda del escenario.

Junto con las proyecciones en vídeo, la música original subraya el carácter cinematográfico del espectáculo que nos muestra a un Lorca bastante inédito y, sin embargo, tan necesario para una comprensión más amplia de su producción artística.

\section{ESPACIOS Y TEMÁTICAS DEL TEXTO}

La acción de Así que pasen cinco años se desarrolla en cuatro lugares principales y dos secundarios:

\section{1) Biblioteca}

La obra se abre en la biblioteca de la casa del Joven. La acotación no aporta datos sobre dicho lugar, pero sí sobre el protagonista y el otro personaje que dialoga con él:

Biblioteca. El Joven está sentado. Viste un pijama azul. El VIEJO de chaqué gris con barba blanca y enormes lentes de oro, también sentado (García Lorca, 2003: 191).

Esta primera acotación nos lleva a una dimensión nueva: enfocando nuestra atención sobre un detalle («enormes lentes de oro») Lorca rompe inmediatamente la posibilidad de una visión normalizada de la realidad. A este propósito Ucelay (2003: 135) indica: «las imágenes [...] aumentan de tamaño o disminuyen como respondiendo al movimiento de una cámara» ${ }^{2}$.

Así que pasen cinco años tiene una estructura narrativa que, con respecto al teatro lorquiano más conocido, desconcierta. También gracias a las acotaciones, durante toda la obra, la atención del lector se orienta sobre unos elementos significativos que insisten en la novedad del texto.

A medida que los diálogos se van desmigajando en el texto, el autor introduce algunos detalles y notamos que «un reloj da las seis», que hay un «sofá sobre el que se sienta y se estira el Amigo 1» y que después hay una mesa sobre la que El Joven «golpea con impaciencia los dedos» (García Lor-

\footnotetext{
2 Para la relación entre Lorca y el cine, véanse también las páginas siguientes.
} 
ca, 2003: 213). En este espacio se desarrollan los diálogos del Joven (protagonista de la obra) y El Viejo, que empiezan in medias res.

El acto I reúne también a otros personajes. Algunos de ellos interactúan con el protagonista (Mecanógrafa, Amigo 1 y Amigo 2) y otros, en cambio, se sitúan en dimensiones paralelas a la del joven y, en cierto modo, evocan su destino. Me refiero, en particular, a la escena del Niño y la Gata recién muertos, situada en una dimensión contemporánea a la acción principal y que aparece como una pantomima o anticipación de la muerte del joven ${ }^{3}$.

Los diálogos del primer acto tienen como tema principal el tiempo y, más concretamente, la espera. El Joven nos informa de que debe esperar cinco años antes de casarse con la mujer a la que está prometido y a la que ama. Intenta colmar su espera la Mecanógrafa que, en cambio, se declara dispuesta a amarlo enseguida: «pero yo no espero ¿qué es eso de esperar?» (p. 207), pero El Joven la rechaza.

Como señala Gullón (1985: 27), la biblioteca de la casa del protagonista es un lugar que impone concentración, «reducción del espacio dramático a interioridad pura». Además, «es un ambiente esencialmente masculino». Nótese que la Mecanógrafa, única mujer del acto, es un personaje que sufre porque no ve su amor correspondido y, por lo tanto, se encuentra en una posición débil. Justamente por esta razón, el ambiente del acto sucesivo aparece femenino en extremo. Lorca acentúa el contraste al componer los detalles.

\section{2) Alcoba estilo 1900 (Casa de la novia)}

En el segundo acto se produce el encuentro del Joven con la Novia. Basándonos en la información recibida en el primer acto, es de suponer que han trascurrido cinco años.

Con relación a la acotación del primer acto, el lugar con el que Lorca abre el segundo queda descrito de manera más detallada:

Alcoba estilo 900. Muebles extraños. Grandes cortinajes llenos de pliegues y borlas. Por las paredes nubes y ángeles pintados. En el centro una cama llena de colgaduras y plumajes. A la izquierda un tocador sostenido por ángeles con ramos de luces eléctricas en las manos. Los balcones están abiertos y por ellos entra la luna (García Lorca, 2003: 245).

${ }^{3}$ Precisamente por su naturaleza de pantomima parece muy apropiado en el espectáculo el uso que el director hace de personajes marionetas para interpretar esta escena. 
Este espacio es necesario en el recorrido del protagonista, ya que representa su primer contacto con la realidad: el Joven, saliendo de su biblioteca (la zona franca que le permite vivir un tiempo personal) descubre que su prometida esposa ya está enamorada de otro, un Jugador de Rugby. La casa de la novia se convierte simbólicamente en el lugar del desengaño.

También en este acto, como sucedía en el primero con la escena del Niño y de la Gata, el autor inserta una escena paralela a la acción principal, la del Maniquí, quien evoca en términos iconográficamente surrealistas las problemáticas del protagonista.

\section{3) Bosque, circo y pequeño teatro}

El primer cuadro del III acto nos lleva a un espacio abierto y bien definido. El bosque es un lugar que encontramos varias veces en la obra dramática y poética lorquiana. Este espacio externo está además pormenorizado; Lorca insiste desde el principio en el detalle para caracterizar su naturaleza ilusoria ${ }^{4}$. Dentro del bosque lorquiano de Así que pasen cinco años encontramos dos lugares secundarios: «un teatro rodeado de cortinas barrocas con el telón echado» (García Lorca, 2003: 292) y un circo («Arlequín: Por ahí está el circo», García Lorca, 2003: p. 310). Ambos son lugares de espectáculo, o sea de ficción, que presuponen la existencia de un público y la actuación de una performance.

El Joven se pierde vagando en este espacio abierto, sube al pequeño teatro, pero evita el circo. Arlequín y el Payaso son dos personajes que nos remiten a la Commedia dell'Arte y cuya presencia en el bosque intensifica la calidad teatral del lugar. Burlándose del Joven, ellos ironizan sobre su desesperación.

El pequeño teatro, en el que se desarrolla parte del encuentro entre el Joven y la Mecanógrafa, posible alternativa a la Novia que acaba de abandonarlo, vuelve a presentar la biblioteca del I acto. A propósito de esta reutilización del lugar, Ucelay (2003: 119-120) indica que se trata de «una inversión escénica del dentro/fuera del primer acto». No parece ser casual que Lorca reproduzca el interior del I acto en un marco exterior que ilusiona sobre la posible realización del sueño. Situada otra vez en un contexto de ficción, la biblioteca - única realidad verdaderamente soportable para el Joven - aparece definitivamente insuficiente para su felicidad.

4 He señalado la naturaleza ilusoria y trágica del bosque en la obra lorquiana en otro estudio mío (Locatelli, 2009). 
En el II cuadro que cierra el acto y la obra, Lorca nos lleva otra vez a este mismo espacio cerrado del que acaba de subrayar la ineficacia.

\section{4) Biblioteca}

En relación con la descripción que hallamos al principio de la obra, esta vez encontramos más detalles sobre los objetos que ocupan el espacio y que se han ido acumulando durantes los actos:

La misma biblioteca que en el primer acto. A la izquierda el traje de novia puesto en un maniquí sin cabeza y sin manos. Varias maletas abiertas. A la derecha una mesa. Sale EL CRIADO y LA CRIADA.

Las maletas abiertas recuerdan el viaje del joven, es decir, el contacto con el exterior y sus consecuencias. La figura del Maniquí, que viste el traje de novia del II acto, antes «con la cara gris y las cejas y los labios dorados [...] peluca y guantes de oro [que] trae puesto con cierto embarazo un espléndido traje de novia blanco [...]» (García Lorca, 2003: 276) y ahora sin cabeza y sin manos, insiste en la precariedad de su posición actual. La amputación de sus extremidades alude a la del sueño de amor y vida del Joven.

Al observar este esquema, notamos que la alternancia en el uso de los espacios dramáticos sigue esta sucesión:

Interior: Biblioteca (ventanas cerradas).

Interior/exterior: Casa de la Novia (balcones abiertos).

Exterior: 1) Bosque y dos lugares secundarios: a) teatro (recreación ambiente cerrado: biblioteca primer acto); b) circo $^{5}$.

Interior: Biblioteca, cierre definitivo.

Este viaje recorre las etapas vitales del protagonista y recalca la fatalidad del contacto interior-exterior en la medida en que significa despertar del sueño, única realidad posible para el protagonista.

A continuación veremos cómo los espacios dramáticos se transforman en lugares del escenario y de qué manera el espectáculo utiliza (interpreta) las directrices lorquianas.

5 Ucelay define el bosque como un espacio externo, «pero un exterior cerrado, acotado, sin más salida que la del circo de los muertos» (2003: 119). 


\section{LOS LUGARES DEL ESPECTÁCULO. METATEATRO, ANTICIPACIONES Y AMPLIFICACIONES DEL TEXTO}

La construcción escénica del espacio hace uso de videoproyecciones. La escenografía es exclusivamente digital y utiliza tres pantallas de plasma de diferentes tamaños, orientando la atención del espectador a través de una escenografía móvil, cinematográfica. El espectáculo respeta y desarrolla el interés lorquiano por el detalle, reproduciendo con precisión «el movimiento de una cámara».

Las escenas representan los lugares descritos en las acotaciones y además amplifican algunos que en el texto quedan solamente esbozados. Observemos cómo:

I acto. La construcción del espacio inicial se conforma a través del vacío y la penumbra. El cuarto que vemos no parece ser una biblioteca. La atmósfera desdibujada por la luz es íntima. En los primeros minutos de la representación no hay libros y encontramos al Joven en el centro del escenario, solo. Detrás de él, en la pantalla que ocupa todo el telón de fondo, se proyectan unas manos que tocan una guitarra. Por lo tanto, al principio del espectáculo, la música sustituye a la biblioteca que aparecerá un poco más tarde, es decir, que sustituye el espacio íntimo y las primeras réplicas del Joven.

El protagonista canta «Balada triste», mientras se dirige hacia el público cruzando perpendicularmente el escenario ${ }^{6}$. Los versos de «Balada triste», al comienzo del espectáculo, tienen la función de poner en contacto al público de una forma inmediata con algunas de las problemáticas y temáticas de la obra. Esta solución permite disipar el carácter críptico del diálogo inicial entre El Viejo y El Joven y presentarnos de manera más accesible al protagonista.

El yo frágil y delicado del poema lo recuerda, así como el tema del tiempo (la espera) unido al desengaño:

¡Mi corazón es una mariposa,

niños buenos del prado!,

que presa por la araña gris del tiempo

tiene el polen fatal del desengaño (García Lorca, 1960: 118).

${ }^{6}$ El poema está fechado en 1918 y forma parte de Libro de Poemas. Observemos que de este mismo año es «Leyenda a medio abrir», poema en el que Lorca declara su interés por la obra «Légend du beau Pécopin et de la belle Baldour», de Victor Hugo, fuente esencial de Así que pasen cinco años. 
A partir de la segunda estrofa, se sugiere una pérdida:

[...] perdí la sortija de mi dicha

al pasar el arroyo imaginario (García Lorca, 1960: 119),

que nos recuerda a la del Maniquí, personaje que simboliza el deseo no realizado y el fracaso del joven:

MANIQUí: Mi anillo, señor, mi anillo de oro viejo,

se hundió por las arenas del espejo (García Lorca, 2003: 277).

También en «Balada triste» hay una espera:

¿quién será la que coge los claveles

y las rosas de mayo? (García Lorca, 1960: 119).

La soledad y la tristeza del personaje del poema son un preámbulo adecuado al destino del Joven:

Yo solo con mi amor desconocido

sin corazón, sin llantos,

hacia el techo imposible de los cielos

con un gran sol por báculo.

¿Qué tristeza tan seria me da sombra!

[...] (García Lorca, 1960: 120).

Soledad, espera del amor y pérdida de la felicidad son los primeros elementos (cantados) con los que nos encontramos en el espectáculo y que trazan el contexto existencial del personaje principal, construyéndolo escénicamente.

Al terminar la canción, en la misma pantalla del fondo se proyecta un espacio exterior: la imagen de un cielo con unas nubes que recuerdan la pintura de Magritte y una breve mirada a la hierba de un prado. La dirección señala inmediatamente el elemento de estorbo de esta biblioteca que es refugio y protección para el Joven (JOVEN: «Ruido, ruido siempre, polvo, calor, malos olores. Me molesta que las cosas de la calle entren en mi casa [...] Juan cierra la ventana», García Lorca, 2003: 197-198).

Solo ahora empieza el verdadero diálogo. Aparece la Mecanógrafa, cuya imagen proyectada en la pantalla, que a estas alturas acoge el cielo con las nubes, cruza el escenario virtual llorando: «(Un reloj da las seis. La Mecanógrafa cruza la escena llorando en silencio)» (García Lorca, 2003: 194). 
En este momento la escenografía digital nos muestra la biblioteca.

Una librería virtual en el centro de la escena es el ambiente donde se desarrolla el diálogo entre El Viejo y El Joven. La librería aloja la Enciclopedia del Espectáculo y de la Música ${ }^{7}$. Este detalle escénico no parece casual, como aclararé más adelante.

En el mismo fondo virtual se alternan los libros en las estanterías y el cielo con las nubes en movimiento. Esta imagen sugiere el conflicto interior/exterior que inunda progresivamente el espacio vital del protagonista.

Después de unas réplicas con el Viejo, el espectáculo vuelve a detenerse en la música y en otra anticipación del texto. El Joven canta la canción de Arlequín, que en el texto escuchamos realmente solo en el tercer acto. La anticipación de la canción, «El sueño va sobre el tiempo», que eleva el espectáculo y el texto en una suspensión surrealista, tiene la tarea, como «Balada triste», de informarnos sobre otra temática importante de la obra: la del tiempo unido al sueño.

Como indica Ucelay (2003: 84), la obra íntegra Leyenda del tiempo es una obra-sueño u obra ensoñación. La actitud del Joven a soñar lo lleva a esperar, impidiéndole vivir el presente y posponiendo la realización de sus deseos. Precisamente esta actitud provocará su muerte.

La anticipación de las temáticas principales de la obra permite además disipar la aparente dificultad del texto e introducir, a lo largo del espectáculo, cuestiones de otro tipo.

$\mathrm{Al}$ espectador se le anticipan algunas informaciones del texto, lo que supone que el acento no recae exclusivamente en la narración, sino en el significado de la obra y en su posición dentro de la producción lorquiana. Es esta una de las características fundamentales de la puesta en escena de Genta y Schiavoni, quienes expresan fielmente el objetivo innovador lorquiano en un teatro que no renuncia al público y que, al mismo tiempo, quiere acostumbrarlo a algo nuevo.

Con respecto a la novedad de Así que pasen cinco años, en uno de sus trabajos más conocido Fernández Cifuentes (1986: 264) sugiere que «es una obra de teatro sobre el tiempo empeñada en perturbar las firmes convicciones del tiempo en el teatro. La alteración o el desorden de ese curso

7 Enciclopedia dello Spettacolo (Firenze-Roma: Sansoni, 1954). Enciclopedia della Musica (Torino: UTET, 1999). Le agradezco al director Marco Schiavoni su ayuda aportándome la información precisa. 
convencional es a la vez el objeto y el procedimiento de la obra». El desorden y la alteración de este curso convencional que enriquecen el texto se utilizan en el espectáculo precisamente con el fin de responder a la exigencia más difícil e intrigante del proyecto lorquiano: crear un teatro de vanguardia que pueda ser representado. Para Lorca, al público se le podía enseñar, es el teatro el que debe imponerse al público, que no al revés.

La construcción escénica del II acto echa luz a este propósito.

II acto: En el espectáculo el acto empieza con la imagen de los balcones abiertos. También en este caso hay una anticipación de las indicaciones lorquianas.

La primera imagen que vemos no es la «Alcoba estilo 900 con muebles extraños y grandes cortinajes llenos de pliegues y borlas» sino la proyección del primer plano de la Novia en el balcón, sonriente y enamorada. Entre ambas imágenes el contraste es rotundo.

En la acotación del comienzo del acto existe efectivamente la referencia a los balcones: «Los balcones están abiertos y por ellos entra la luna» (García Lorca, 2003: 245), pero en el texto la descripción detallada del cuarto de la Novia, que no aparece en el escenario, precede esta indicación.

Pasando directamente de la proyección de la biblioteca, en la pantalla grande del primer acto, al balcón, se subraya que el contraste interior/exterior se propaga en otro contraste emblemático: Joven/interior/sueño $v s$. Novia/exterior/realidad (FOTO 1).

Los primeros planos aparecen en las tres pantallas y multiplican la cara de la Novia llenando el escenario. El zoom es irrefrenable, lo cual amplifica el ambiente femenino del texto arrastrando al espectador a una dimensión diametralmente opuesta a la imagen dibujada por el Joven en el primer acto.

Las pantallas proyectan sin piedad esta nueva imagen y amplifican el monólogo de la Novia que Lorca construye a sabiendas de manera apasionada e insistente. Las imágenes en vídeo son inclementes. El monitor principal agiganta la traición enseñándonos al hombre del que la Novia está enamorada abrazándola, y añade imágenes que intensifican la diferencia entre el sueño del Joven y la realidad. Las pantallas dan una imagen dilatada y artificial de su sensualidad. Para evidenciar el contraste, los dos artistas se inspiran en un icono femenino (Marilyn Monroe, con foto de Tom Kelley, de Real Velvet Collection) y adaptan la imagen al personaje lorquiano. (FOTOS 2 y 3 ).

Junto con este aspecto cinematográfico y esta dimensión ficcional, también la actuación se orienta hacia una dimensión exagerada y consciente por 
parte de los actores, abriendo paréntesis metateatrales que son un elemento fundamental de la obra.

En el monólogo de amor de la Novia que abre el segundo acto, la insistencia sobre los primeros planos que se multiplican en cada pantalla es contemporánea a su presencia física en escena. El escenario está vacío y sólo aparece una silla en la que la actriz, sentada, dirige sus palabras al querido Jugador de Rugby del que tiene en la mano sólo la cabeza de amlética memoria. El acento puesto en una hiper-actuación, la cabeza del Jugador en la mano cual calavera de Yorik y la música de fondo ${ }^{8}$ contribuyen a la construcción caricaturesca de la mujer enamorada que más que sobre la Novia ironiza sobre el sueño del Joven, precisamente como harán el Payaso y el Arlequín en el bosque del III acto.

Las pantallas que rodean a la actriz monologando perseveran en esta dimensión cinematográfica y ficticia. (FOTO 4).

Las siguientes proyecciones en vídeo nos presentan un armario lleno de trajes de diferentes colores que invitan a la Novia a elegir el vestido para la cita con su prometido. También en este caso asistimos a una ampliación significativa de las indicaciones lorquianas: Lorca habla de trajes, pero no de un armario ("Criada: [...] le da los trajes.”) (p. 254). El espectáculo construye metonímicamente el lugar a través de las pantallas. Los trajes se transforman en un armario que se encuentra en el fondo del escenario, en la pantalla grande mencionada anteriormente. En este contexto se produce el encuentro entre los dos.

La acción imparable del contraste sueño $v s$. realidad se muestra también en la construcción de la escena sucesiva en la que el padre de la Novia le suplica que se case con el Joven, quien ha estado esperándola durante cinco años.

Tal como ocurre con el monólogo de la Novia, realizado escénicamente de manera tan redundante que parece una caricatura de los monólogos de amor, también esta escena propone parodísticamente la relación padre e hija. Es una relación antitética con respecto a la visión clásica. El padre de la Novia de Así que pasen cinco años no presenta un carácter impositivo y la dirección de Schiavoni subraya la inversión de los papeles de la relación genitorial respecto a la de otras obras lorquianas ${ }^{9}$. Él está distraído y mientras

\footnotetext{
${ }^{8}$ La décima Sinfonía de Mahler, La Incompiuta, única música no original del espectáculo.

9 Pensemos, entre otros, en la despótica Bernarda Alba, en la fuerte y matriarcal madre de Bodas de sangre, en el padre de la Novia en la misma obra que con ella concuerda el matrimonio o, también, en las frías guardianas de Yerma, hermanas de su esposo, que no son padres, pero sí representantes de un vínculo familiar.
} 
«(hace intención de pegarle)», como consecuencia de sus frecuentes rechazos, piensa en otras cosas: "todo contra mí. (Mira al cielo por el balcón abierto). Ahora empezará el eclipse. (Se dirige al balcón.) Ya han apagado las lámparas. (Con angustia.) !Será hermoso!» (García Lorca, 2003: 263).

La actitud con la que la novia se encara con el padre se mofa de la extenuante espera del novio, insistiendo en la ilusión del amor y de la esperanza. La escena nos muestra al personaje mientras repite los movimientos de un vídeo de aeróbica proyectado sobre una pantalla televisiva que se enciende a su antojo cuando chasquea los dedos.

Al mismo tiempo, el padre - cuya petición es cada vez menos creíble y realizable -, proyectado sobre otra pantalla de plasma, mira las estrellas con el binóculo.

Después de la lección de aeróbica llega el Joven. Su imagen es proyectada exactamente en la misma pantalla. Le vemos en primer plano, pero su cara, contrariamente a la de la Novia, cuya imagen anteriormente se multiplicaba sobre las pantallas de varios tamaños, está a propósito proyectada en un lado del escenario, descuidada y aquejada. De este modo, él queda encerrado en un espacio más pequeño que le remite a su destino de perdedor.

Los tamaños de los monitores tienen también esta función: subrayar la importancia y la simbología de las imágenes.

El diálogo entre los dos acentúa el desengaño. Todavía con la esperanza de encontrar una moza inocente con trenzas el protagonista se enfrenta de nuevo a la realidad: «Joven: [...]....las trenzas... Novia: Nunca tuve trenzas» (García Lorca, 2003: 266).

El espectáculo persevera implacable en lo engañoso del sueño: la Novia se acerca impetuosamente a la pantalla en la que está proyectada la cara del joven y se arranca la peluca de la cabeza, actuando de esta manera como una actriz que se desnuda del vestuario de ficción al final de la representación. Este gesto pone otra vez de relieve la dimensión teatral de Así que pasen cinco años, obra en la que, como he indicado, el metateatro no se limita a momentos del texto, sino que sugiere el discurso amplio e innovador de Lorca sobre el teatro.

El momento de la separación entre los dos está construido con una eficacia pictórica, la lluvia inunda el vídeo. Sobre la pantalla, a la izquierda, el agua cae a cántaros y su sonido se convierte en el fondo sonoro del abandono de la Novia. Se anticipa aquí un elemento simbólico que pronto será predominante. De hecho, en el monólogo del Maniquí, cuya «cola se pierde en el mar» (p. 277), la referencia al agua vuelve a repetirse diez veces. 
Cuando la Novia sale de la escena, el Maniquí que viste el traje de Novia viene del armario. La escenografía cambia, en el fondo se proyecta el mar que quedará visible durante todo el monólogo de este personaje que expresa la paternidad frustrada y el desperdicio del amor.

Proyectando el mar en movimiento sobre la pantalla más amplia se patentiza de manera preponderante su simbología.

Será oportuno recordar que el mar, en la tradición psicoanalítica y en el imaginario colectivo, es un lugar común metafórico y evoca siempre a la madre. Afrodita que nace de las aguas es una imagen metafórica del parto. Es la madre como lugar de origen. El Maniquí de Así que pasen cinco años sale del mar y se dirige hacia el público con el traje de Novia en los brazos. Sin cuerpo y llevado por la actriz entre los brazos, el traje de Novia nos da la medida del sufrimiento por la frustración genitorial. El vídeo multiplica insistentemente la imagen de la figura blanca que avanza hacia el público hasta inundar el escenario y aclarar sin más dudas su función en la pieza.

En este momento de pasaje del Joven, que va desde la pérdida de la Novia hasta la búsqueda de la posibilidad de concretar su sueño de amor, en el vídeo que concluye el II acto hay otra anticipación del texto. Aparece la Mecanógrafa, que en la obra vuelve solo en el III acto. Nos avisa de su llegada la imagen de ella en la playa, sentada frente a la máquina de escribir. Justo después de la pregunta del Maniquí: «¿Quién se pondrá mi traje?», la Mecanógrafa parece convertirse en la respuesta a esta cuestión. El espectáculo nos introduce en el acto final.

III acto. Cuadro primero. Las pantallas en el escenario reconstruyen el bosque, difuminando la imagen del mar con la luna que en él se hunde. El sonido del mar que acompaña el tránsito entre el II y el III actos crea una fusión de lugares y de sus simbologías. La contemporaneidad del mar y del bosque es remarcada justo después, cuando el vídeo central, dividido en dos partes, nos muestra, a la izquierda, al Joven, cuyo fondo es el bosque (lugar que ilusiona la posibilidad de realizar los sueños) y, a la derecha, la Mecanógrafa en el mar (símbolo de maternidad y, por lo tanto, de la posibilidad de un futuro).

La alternancia del mar y del bosque está siempre en todas las pantallas del escenario. La Mecanógrafa viste el traje de Novia. Esta decisión escénica marca su papel en las esperanzas del Joven ${ }^{10}$.

${ }^{10}$ En la acotación del texto: «Sale La MECANÓGRAFA. Viste un traje de tennis con boina de color intenso» (García Lorca, 2003: 303). 
La escena entre los dos, que en el texto se resuelve en el pequeño tablado en el bosque, renuncia a la presencia del pequeño escenario, pero mantiene el carácter metateatral.

En la acotación del texto en la que se indica «las luces del teatro se encienden» (p. 313), la puesta en escena reconstruye a su vez una dimensión representativa, amplificándola. Los actores actúan conscientes de la presencia del auditorio. En comparación con el monólogo de la Novia que abre el II acto, aquí la estrategia a la que recurre el director es distinta. Ambos personajes interactúan a través de dos micrófonos, cantando sus réplicas como en un melodrama.

La respuesta a las palabras de amor del Joven, que es cantada por la Mecanógrafa frente a su micrófono, ironiza sobre su concretización. La espera de otros cinco años, que en el texto tiene una trágica fuerza dramática, aquí está subrayada con una atmósfera paródica lograda a través de la dimensión melodramática del diálogo.

Como ya he mencionado, la referencia al teatro en Así que pasen cinco años es predominante. En la pieza es constante la utilización de personajes de la tradición teatral como lo son la Máscara, el Arlequín, el Payaso y también la presentación concreta del teatro como lugar de ficción. Esta característica de la obra se enfatiza en la puesta en escena. A través de las pantallas los personajes son creados en una dimensión ficticia como en una especie de juego de cajas chinas, porque están obligados a una dimensión virtual dentro de otro espacio de ficción que es el escenario. Por otro lado, la hiperactuación señala la falta de credibilidad del contexto en el que se expresa el amor, ya que un aura de irrealidad lo caracteriza.

Desde los movimientos en vídeo del Viejo y las réplicas pronunciadas por otros personajes que caricaturizan las palabras del Joven burlándose de su gravedad, pasando por los momentos de metactuación en algunas escenas, el metateatro resulta necesario precisamente porque expresa la tragedia del destino del protagonista y aclara que sus deseos no pueden realizarse. Al Joven no le está permitido soñar y la inexorable ostentación de la naturaleza ilusoria del sueño (el teatro) lo reitera.

Cuadro último: la biblioteca. La escenografía nos presenta otra vez el mismo entorno del primer acto. En las pantallas se suceden los diálogos del texto hasta el juego de naipes en el que el Joven pierde. En una rueda de cartas de juego en movimiento, proyectada sobre el telón de fondo, el Joven pierde la vida cuando descubre su as de corazones. El escenario está vacío de 
nuevo, como al principio de la representación. Alrededor del protagonista el espacio está privado de elementos; cabe apuntar que el director Schiavoni pretende mostrar al Joven en su camino al revés hacia un destino temido, antitético al inicial, donde levanta los brazos antes de abandonar la escena y, a merced de sí mismo, aparece como un mártir. Ya no existe la guitarra y los vídeos ya no proyectan nada.

\section{PANTALLAS, SURREALISMO Y TRAGEDIA}

A través de este recorrido por los lugares del escenario se observa que el espectáculo desarrolla generosamente las indicaciones lorquianas, insistiendo en aquellos elementos significativos del texto que crean momentos claves, tanto en el desenlace de la acción como en el desarrollo de los personajes. La dirección multiplica el potencial de la obra, gracias a pantallas que proyectan figuras bidimensionales, sus primeros planos reiterados y contextos dibujados con una eficacia que muestra puntualmente la inevitabilidad de los conflictos del drama.

La construcción pictórica del espacio remite a la pintura metafísica y surrealista. El escenario está en algunas ocasiones vacío y en otras habitado por objetos de proporciones no reales y personajes virtuales que nos facilitan el descubrimiento de la soledad del Joven, perturbando las vías normales de representación.

La importancia del tiempo en su versión íntima (la del Joven) y real (la que el Joven no logra vivir) envuelve el escenario y el teatro mediante la presencia de relojes, agujas, objetos dispares, marionetas y maniquíes que rellenan el espacio virtual, creando una suspensión en la que lo trágico se intuye de manera constante, pero aún no se observan sus efectos.

El del Joven es un tiempo inmóvil y, sin embargo, contemporáneo al tiempo en movimiento. Para expresarse se sirve de la construcción visual de dimensiones paralelas a través de los monitores. El uso del tiempo es personal para cada personaje, que es una isla auto-suficiente y que, al mismo tiempo, funciona solo en relación con los demás, con los que genera un archipiélago. A este propósito Ucelay (2003: 84) comenta:

Cada uno de los caracteres representa su propia parte de tiempo intrasferible que se proyecta en la escena no siguiendo una secuencia, sino funcionando en distintos planos interpolados o combinados sin prescindir de ninguna de sus posibilidades. Todos tienen su relación particular, solo suya, con el tiempo ya sea en una u otra de sus dimenciones. 
Fielmente al núcleo del texto, el espectáculo reconstruye una dimensión surreal y trágica que nos ilumina sobre aquel lugar de tránsito y suspensión entre dos visiones del arte que en Lorca se hallan perfectamente compenetradas.

Con la ayuda de las proyecciones en vídeo, de la danza y del canto, el final del Joven cruza el espacio en suspensión y parece solo rozar la fuerza telúrica de la tragedia, pero en realidad proviene de esta como un mártir predestinado. El Joven tiene que morir, «su nombre abstracto, después de todo, lleva implícita su temporalidad» (Ucelay, 2003: 81).

Estamos llamados a asistir a una sagrada representación interior donde no existe el gusto por la personalidad escindida, sino la más terrible tragedia - infinitamente humana y real - de los mecanismos contradictorios de la mente. Es precisamente el lado enigmático de la realidad el que Lorca pretende transmitir en su intento de crear un Surrealismo diferente. No estamos frente a una necesidad narcotizante o automática de creación, sino a una necesidad imprescindible de comprender y reproducir a través del arte y, por lo tanto de manera liberamente artística, la realidad. El dramaturgo usa el lenguaje y el ambiente de los sueños precisamente porque lo cree real.

Así que pasen cinco años es un trabajo emblemático de esta visión y propuesta lorquiana. Como bien ha remarcado Bizzarri (2008: 103), con Lorca estamos ante «un surrealismo humano que rechaza el experimento onírico, parándose a medio camino en una dimensión sonámbula, en la que la imagen borrosa sugiere, sin pronunciarlas, verdades dolientes, humanamente reconocibles ${ }^{11}$. Una dimensión sonámbula, de duermevela, que es evidente tanto en el texto como en la puesta en escena, donde la música que abre el espectáculo, el uso de las luces y la construcción del espacio escénico nos llevan con facilidad a una dimensión suspendida y onírica ${ }^{12}$.

Los personajes que rodean al Joven especialmente en el I acto no son nada más que sus proyecciones humanas, sus alter egos. A propósito de este desdoblamiento o multiplicación Ucelay (2003: 78-79) indica:

${ }^{11} \mathrm{El}$ autor que cito se refiere a Romance sonámbulo y, en particular, al interés de Lorca por las «Canciones de cuna españolas». Este análisis me parece apropiado en el caso de la obra teatral que analizo y, más concretamente, en todo tipo de obras surrealistas lorquianas. De hecho, la dimensión sonámbula es distinta de la verdaderamente onírica promulgada por los surrealistas puros, como por ejemplo Dalí y Buñuel. Sobre el diferente Surrealismo lorquiano véase, entre otros, Huélamo (1989).

${ }^{12}$ La primera acotación que abre Así que pasen cinco años nos presenta al Joven en pijama, indumento que generalmente lleva puesto quien duerme (sueña). Más adelante la actitud del Joven quedará confirmada por el Viejo: «iSueña tanto!» (p. 200). 
En el primer acto el tema del Tiempo ocupa el diálogo de El joven y sus alter egos. Lorca está haciendo lo que hiciera ya Góngora, que como él mismo nos dice: «Dobla y triplica la imagen para llevarnos a planos diferentes» necesarios «para redondear la acción y comunicarla con todos sus aspectos».

Esta multiplicación, que se expresa en el espectáculo a través de la construcción de los personajes en el vídeo, insiste en una insuficiencia que desencadena la imposibilidad del deseo. A través de los personajes virtuales y sin cuerpo podemos observar lo ilusorio del sueño y la espera del protagonista. Del mismo modo que el Joven «no sólo [...] protagonista, sino la obra misma propiamente» (Ucelay, 2003: 78) se descompone trágicamente en proyecciones no conscientes de sí mismas, la bidimensionalidad de los personajes en vídeo subraya su inadecuación.

Ciertamente la meta se intuye desde el comienzo del drama, pero es opaca e ilusoria, con apariciones donde él camina a tientas como una marioneta sin hilos, en la oscuridad de sí mismo, engañosamente iluminado por mares y nubes en movimiento.

Las pantallas subrayan visualmente el hilo onírico de la pieza. Como es sabido, las obras surrealistas combinan provocativamente entre sí elementos extraños y lejanos, reproduciendo a través de los mecanismos de desplazamiento y condensación, característicos de los procesos inconscientes, una dimensión onírica en la que se relacionan cosas aparentemente irrelacionables entre sí. Las pantallas permiten una visión contemporánea de imágenes que no están racionalmente conectadas; ofrecen una fusión de acontecimientos, personas y emociones con la ayuda de la música y el baile. De esta manera, el espectáculo reúne en una dimensión de sueño no solo a los personajes del drama, sino también a los espectadores.

Aunque Así que pasen cinco años es una pieza representativa de un Surrealismo infinitamente personal, se presta particularmente a esta puesta en escena. Varios diálogos se alejan de una narración lineal y algunas escenas paralelas y contemporáneas a la acción principal son relevantes ${ }^{13}$.

En la necesidad de multiplicarse para adquirir un significado global o, si queremos, en su descomponerse trágicamente en proyecciones no conscientes de sí mismas, El Joven lorquiano nos comunica su muerte inevitable. En esta no es difícil vislumbrar el destino del mismo autor, especialmente si nos

13 Piénsese por ejemplo en la escena del Niño y la Gata que fija en una imagen congelada el diálogo entre el Joven y sus huéspedes o en aquella del Maniquí, aparición imprevista y surreal. 
fijamos en la fecha preconizada por el manuscrito autógrafo: 19 de agosto de 1931. Exactamente cinco años después, Lorca será fusilado.

Superrealidad y dimensiones paralelas junto a fuerzas telúricas e inevitabilidad de lo trágico son elementos expresados a través de una puesta en escena multimedia que no cae en la imprecisión, sino que tiende a la exactitud, calidad tan importante para Lorca.

El espectáculo de Caterina Genta y Marco Schiavoni hace justicia a un texto difícil y poco representado de Lorca, no solo disipando los puntos aparentemente crípticos, sino indicando la función fundamental de Así que pasen cinco años en la producción del autor andaluz y otorgándole su papel, inconsciente y terrible, de testamento artístico.

\section{REFERENCIA BIBLIOGRÁFICAS}

BIZZARRI, G. (2008). La rappresentazione del sovrannaturale nelle letterature ispaniche tra Ottocento e Novecento. Tradizioni, leggende, racconti fantastici, assurdità surrealiste e «realismi magici». Padova: CLEUP.

FERNÁNDEZ CIFUENTES, L. (1986). García Lorca en el teatro: la norma y la diferencia. Zaragoza: Prensas Universitarias.

GULLÓN, R. (1985). «Perspectiva y punto de vista en el teatro de García Lorca». En La casa de Bernarda Alba y el teatro de García Lorca, Ricardo Doménech (ed.), 13-30. Madrid: Cátedra.

HUÉLAMO KOSMA, J. (1989). «La influencia de Freud en el teatro de García Lorca». Boletín de la Fundación Federico García Lorca 6, 59-86.

GARCÍA LORCA, F. (1960). Obras completas, Arturo del Hoyo (ed.), Jorge Guillén (pról.), Vicente Aleixandre (epíl.). Madrid: Aguilar.

- (2003). Así que pasen cinco años, Margarita Ucelay (ed.). Madrid: Cátedra.

LOCATELLI, M. (2009). «Así que pasen cinco años y la tragedia». Theatralia. Revista de poética del teatro 11, 89-111. 


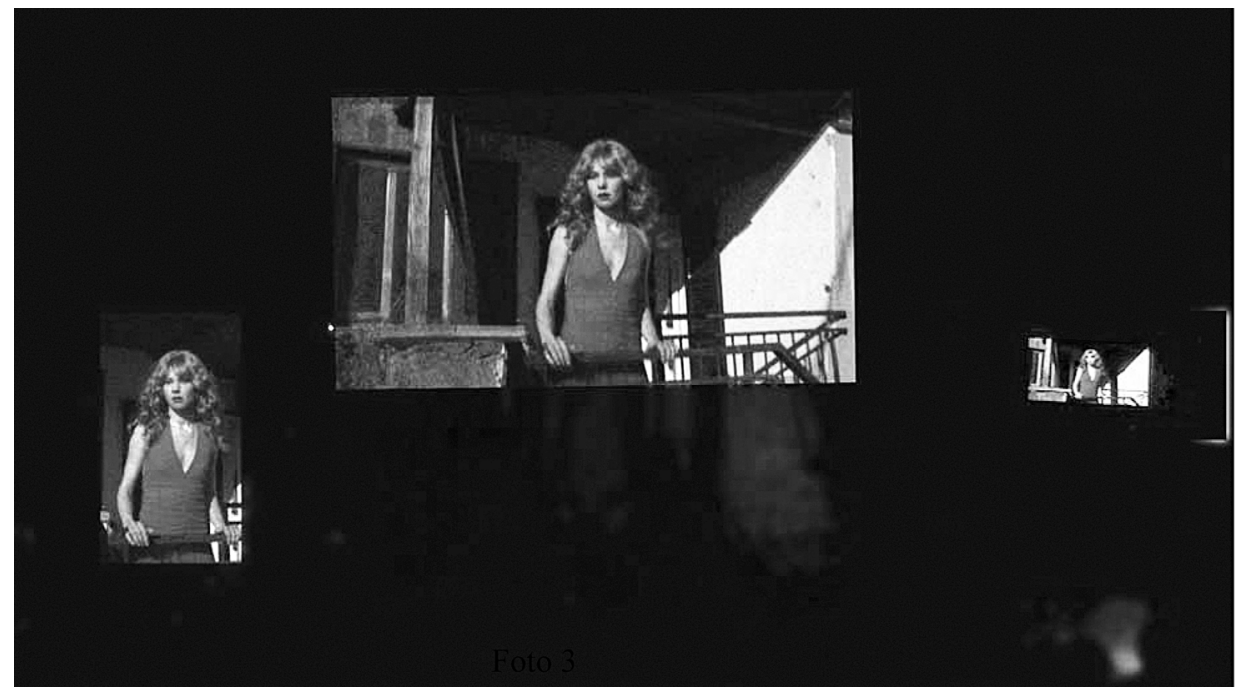

FOTO 1

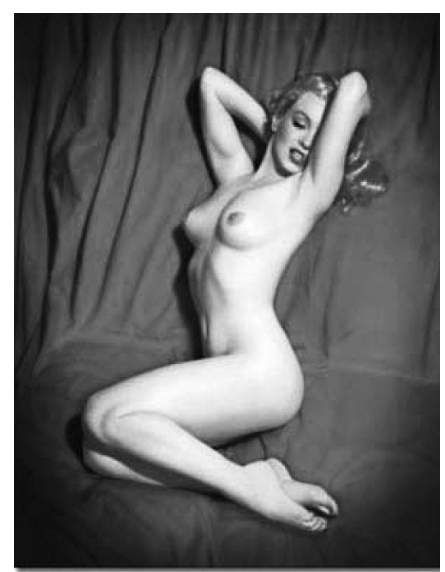

FOTO 2

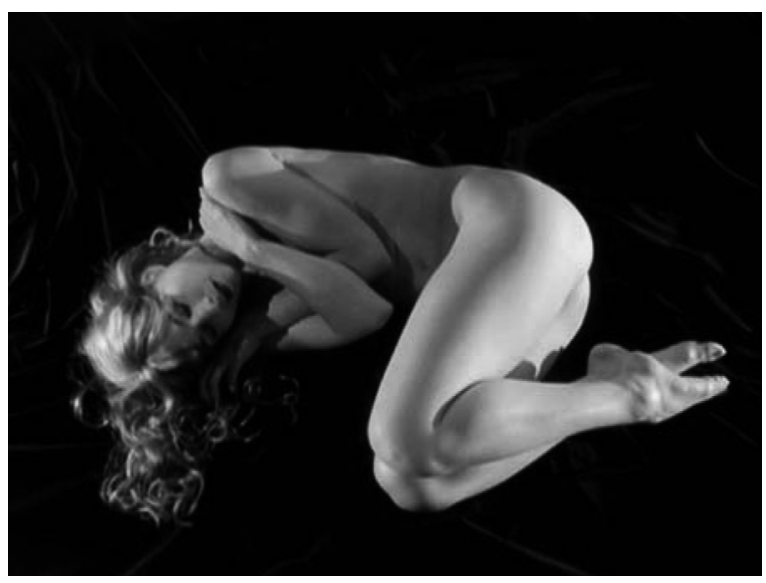

FOTO 3 


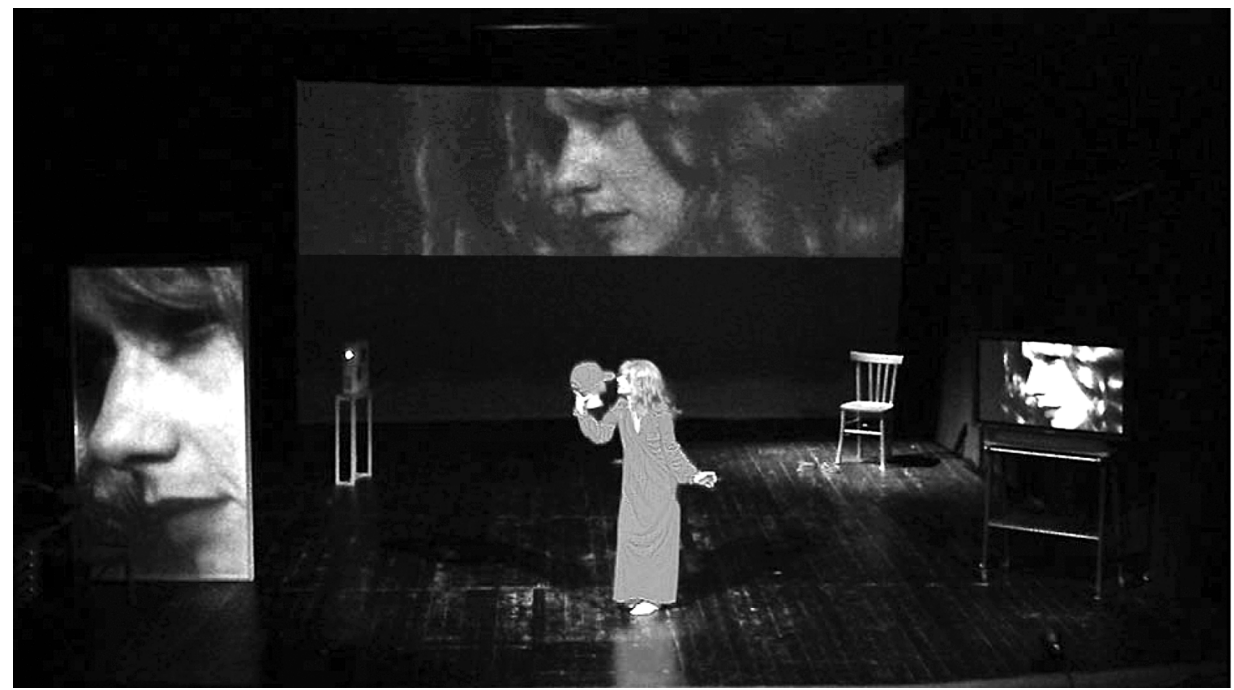

FOTO 4 